\title{
Harnessing the Past for Present Purposes: Self-Reflexivity in Researching and Teaching Western Australian Gay History
}

\author{
Bri McKenzie \\ Curtin University
}

Abstract: Contemporary historians and educators have a responsibility to highlight marginalised voices in their research and teaching work. The past experiences of gay and lesbian Australians is one area of historical study that should thus be further explored and discussed in undergraduate history courses. Yet, the historical research process must always be informed by a self-reflexive questioning of the role of contemporary discourses in the analysis of past events. This article describes some of the challenges that arise when teachingfocused researchers aim both to highlight new historical knowledge and address the silencing of marginalised voices in the classroom. An exploration of a 1931 Western Australian 'unnatural offence' case initially appeared to highlight some historically unique characteristics and apparently fitted neatly into contemporary discourses around the historical marginalisation and victimisation of gay men. However, the case threw up many questions about the role of the researcher in historical research and reinforced the relevance of self-reflexive practice for historians. Harnessing the past for present purposes has many pitfalls but also some unexpected educative benefits.

Australia's contemporary social context has demanded a re-evaluation of our relationship to gay and lesbian history. Interest in the 40th anniversary of the first Australian Mardi Gras march in 1978 along with the success of the marriage equality campaign have led to a growing awareness around queer issues. ${ }^{1}$ With the inevitable backlash that comes

1 Some recent publications on contemporary gay history include Dino Hodge ed., Colouring the Rainbow: Blak Queer and Trans Perspectives (Mile End: Wakefield Press, 2015); Robert Reynolds and Shirleene Robinson, Gay \& Lesbian, Then \& Now: Australian Stories from a Social Revolution (Carlton: Black Inc., 2016); Alex Greenwhich and Shirleene Robinson, Yes Yes Yes: Australia's Journey to Marriage Equality (Sydney: NewSouth Publishing, 2018); Noah Riseman, Shirleene Robinson and Graham Willett, Serving in Silence: Australian LGBT Servicemen and Women (Sydney: NewSouth Publishing, 2018). 
with such social progress, it has become more pressing for historians to seek out and represent queer stories from the past or risk the development of a new era of silencing. At the same time, contemporary discourses in education emphasise the importance of the inclusion of marginalised voices. Nowhere is this more apparent than in recent, international efforts towards curriculum 'queering' at primary and secondary school level. ${ }^{2}$ As social justice educators Jeffry D. Zacko-Smith and G. Pritchy Smith suggest:

Educators must ... accept their role as mentors who help to define reality for those they are educating, and they must commit to redefining that reality as dictated by demands for social justice and equality. ${ }^{3}$

Within this discourse, the emphasis remains on educators to bring about important and significant shifts in relation to how they choose to represent historically marginalised groups to students. In the tertiary context, there is much that can be done by researchers, lecturers and tutors to address the entrenched marginalisation of queer voices.

My own efforts to reimagine the stories of gay men in 1930s Western Australia (WA) formed part of an overarching pedagogical intention to redress the traditional silencing of gay histories and identities in my teaching work. As part of my teaching practice, informed by my specific research interests, I sought to present positive alternative stories of homosexual subcultures in the past within a specific (and neglected) geographical and temporal context. The initial results of this project, however, did not assist me in my efforts to redress the historical silencing and misrepresentation of gay men. Instead, the outcomes of the study necessitated the ongoing examination of my own teaching and research processes through a deeper engagement with self-reflexive practice.

During my research I examined a number of newspaper reports on 'unnatural offence' cases that occurred in Perth during the 1930s. The inclusion of paedophilia, bestiality and homosexual acts under the one

2 See, for example, S. J. Miller, Teaching, Affirming, and Recognizing Trans and Gender Creative Youth: A Queer Literacy Framework (New York: Palgrave Macmillan, 2016), doi.org/10.1057/978-1137-56766-6; Nelson M. Rodriguez and William Pinar, eds, Queering Straight Teachers: Discourse and Identity in Education (New York: Peter Lang, 2007); William Pinar, 'Queer Theory in Education', Journal of Homosexuality 45, no. 2-4 (2003): 357-60, doi.org/10.1300/J082v45n02_21.

3 Jeffry D. Zacko-Smith and G. Pritchy Smith, 'Recognizing and Utilizing Queer Pedagogy', Multicultural Education, (Fall 2010): 2-9. 
broad banner of 'unnatural offence' serves to highlight the discrimination faced by gay men at this time. Of the cases I identified, one in particular stood out: the case of Keith Edwin Gibson, a bank messenger aged 35. Gibson was arrested by Perth police in January 1931 and charged with having 'carnal knowledge' of Clarence George Edward Cummings, then aged $16 .{ }^{4}$ Clarence and Keith had been having sex with each other since early December 1930, but the younger man's willingness to continue the relationship was brought into question when he reported Keith to the police roughly one month later. At trial, however, Clarence retracted his accusation under cross-examination, accusing the police of having coerced him into pointing the finger at Keith. Keith was discharged while Clarence was charged with perjury and with having allowed an 'unnatural act' to be performed on him. He was later sent to the Children's Court. ${ }^{5}$ At this second trial, Clarence subsequently retracted his accusations against police and revealed that Keith had pressured him to withdraw his initial allegations. Clarence's evidence indicated that he felt used by Keith and that the sexual relationship between them had been unwanted.

This case study initially appeared to highlight the classic demonisation and marginalisation of a consensual sexual relationship between two men, but the truth of the case ultimately worked to undermine and problematise my approach to the research. My failed attempt to harness the past for present purposes necessitated self-reflexive analysis of my role as researcher and teacher. Through this process I was able to develop an unexpected new component to my teaching of third-year history students who were themselves engaged in their first major research projects.

In this paper I will argue for the importance of self-reflexivity in teaching practice at tertiary level within the specific context of the discipline of history. Through an analysis of the Gibson 'unnatural offence' case, I will explore some of the possibilities for self-reflexive practice in history teaching. First, the paper discusses current literature on self-reflexivity and its importance to history research and teaching. I follow this with a brief discussion of the historical context of the Gibson case and some commentary on primary sources. I then analyse the case study itself and

4 See, for example, Police Gazette, 18 February 1931, 95; Police Gazette, 25 March 1931, 165. Accessed through Battye Library, State Library of Western Australia (SLWA). See also 'March Criminal Sessions', Mirror, 28 February 1931, 3.

5 'Perjury Charge. Youth Under Arrest', Sunday Times, 29 March 1931, 2; 'Boy Charged with Perjury', West Australian, 27 March 1931, 16. 
this is followed by a discussion of how the circumstances of the case, along with my intentions for the research, highlighted the importance and application of self-reflexivity in my teaching work.

\section{Self-Reflexivity in Historical Research and Teaching}

Social science researchers have long been aware of the way they influence their own interpretations of seemingly 'objective' events. ${ }^{6}$ Moreover, as professional studies specialist and academic Donald E. Hall in his book The Academic Self: An Owners Manual highlights, contemporary academics working in tertiary settings are uniquely trained to integrate self-reflexive practice into their research and writing. As Hall notes:

Living in the late-modern age, and trained as skilled critical readers, we academics in particular have the capacity and the professional skills to live with a critical (self-) consciousness, to reflect critically upon self-reflexivity, and to use always our professional talents to integrate our theories and our practices. ${ }^{7}$

The relevance of self-reflexivity and the inclusion of the self as both researcher and object of research has also been identified as integral to understanding the historical research and writing process. That historical writing is predicated on the selection, construction and interpretation of historical sources by subjective actors has been well established. ${ }^{8}$ More recently this has been connected to the sociological concept of selfreflexivity. As contemporary historical theorists Alun Munslow and Robert A. Rosenstone have suggested, 'self-reflexivity is also the appreciation that history is a literary-creative act even when the aim might seem to be reconstruction. All reconstructions are, of course, constructions.'

6 See, for example, S. Reinharz, 'Who Am I? The Need for a Variety of Selves in the Field', in Reflexivity and VOICE, ed. R. Herz (Thousand Oaks: Sage, 1997), 3-20.

7 Donald E. Hall, The Academic Self: An Owner's Manual (Columbus: The Ohio State University Press, 2002), 5.

8 See, for example, Hayden White, 'Interpretation in History', in Tropics of Discourse: Essays in Cultural Criticism, ed. Hayden White (Baltimore: John Hopkins University Press, 1986), 51-79.

9 Alun Munslow and Robert A Rosenstone, 'Part I: Self-Reflexive', in Experiments in Rethinking History, ed. Alun Munslow and Robert A Rosenstone (New York: Routledge, 2004), 14. 
In 'Reflexivity and the Self-Line', historian Ann McGrath asks the reader: 'As well as self-reflexivity, do we have a special obligation to share the journey of scholarship, to be reflexive about the research and writing process?' ${ }^{10}$ Such reflections are significant for those of us teaching history and research skills to students. It could be argued that, as teaching academics, it is incumbent upon us to share our research successes and failures with students in an effort to better highlight common pitfalls. Finding the 'self-line' should be a priority for researchers. As teachers of history who aim to share our research skills, we should challenge ourselves to throw off our 'historian's disguise' and engage with our own roles in historical interpretation and representation. ${ }^{11}$

Similarly, in their article 'Self-Study in Teaching and Teacher Development: A Call to Action', education scholars Kathleen Pithouse, Claudia Mitchell and Sandra Weber emphasise the importance of selfreflexivity in teaching practice. Teaching, in tertiary contexts as well as in others, is potentially messy and unpredictable. ${ }^{12}$ Indeed, we can see the unpredictability of both teaching and research as one of the factors that necessitates self-reflexivity in both contexts. In undertaking research into homosexual subcultures and encountering unexpected challenges that required ongoing self-reflexivity in both the teaching and research context, I was engaging in what Pithouse, Mitchell and Weber see as one of the key aspects of self-study in teaching. In this context, 'mucking about, making mistakes, changing one's mind are not viewed as shameful, but rather as learning opportunities that can provoke creative solutions'. ${ }^{13}$ The contradictory results of my research into the Gibson 'unnatural offence' case thus became an opportunity to engage a 'creative solution', one that enabled me to communicate to students the importance of the researcher as an active agent of historical interpretation.

There is also an active connection between self-reflexive practice and queer theoretical and pedagogical approaches. Because queer theory emerged both from and in resistance to existing Western intellectual traditions, it is necessary for queer theoretical approaches to address the inherent

10 Ann McGrath, 'Reflexivity and the Self-Line', in Writing Histories: Imagination and Narration, ed. Ann Curthoys and Ann McGrath (Clayton: Monash University Press, 2009), 07.9.

11 McGrath, 'Reflexivity and the Self-Line', 07.10.

12 Kathleen Pithouse, Claudia Mitchell and Sandra Weber, 'Self-Study in Teaching and Teacher Development: A Call to Action', Educational Action Research 17, no. 1 (2009): 46, doi.org/10.1080/ 09650790802667444.

13 Pithouse, Mitchell and Weber, 'Self-Study', 47. 
inequalities embodied in these dominant narratives. ${ }^{14}$ The un-reflexive nature of dominant narratives is one factor that feeds inherent inequality. As such, queer theoretical approaches must ensure they engage with self-reflexivity in order to remain relevant. As Heather Sykes has identified:

Queer theory has always had to monitor if, and how, it is producing fixed, exclusionary or domesticated ways of thinking about nonnormative sexualities and genders. Like feminist research, queer research has to be critically self-reflexive about how genders and sexualities are formed within local contexts and geopolitical relations of power. ${ }^{15}$

Pithouse, Mitchell and Weber also emphasise the links between self-study in teaching and social action. Specifically, because teaching and research alter us and necessitate change and growth, they can be radically transformative. ${ }^{16}$ As such, self-reflexivity can be understood as not only an essential aspect of our research and teaching work in history generally, but also a particularly important practice in the space of queer history, where our pedagogical approaches should seek to engage with the needs of social justice.

\section{The Representation and Historiography of Queer Subcultures}

There has been a steady stream of historical and sociological research interest in the experiences of gays and lesbians in Australia since the 1990s, some of it produced by longstanding activists for LGBTQI+ rights. ${ }^{17}$ However, very few publications have dealt with the Western Australian history of

14 Heather Sykes, 'Un-Settling Sex: Researcher Self-reflexivity, Queer Theory and Settler Colonial Studies', Qualitative Research in Sport, Exercise and Health 6, no. 4 (2014): 584, doi.org/10.1080/21 59676X.2014.893899.

15 Sykes, 'Un-Settling Sex', 584.

16 Pithouse, Mitchell and Weber, 'Self-Study', 48.

17 See, for example, Robert Aldrich and Garry Wotherspoon, eds, Gay and Lesbian Perspectives IV: Studies in Australian Culture (Sydney: University of Sydney, 1998); David L. Phillips and Graham Willett, eds, Australia's Homosexual Histories: Gay and Lesbian Perspectives $V$ (Sydney: Australian Centre for Lesbian and Gay Research, 2000); Graham Willett, Living Out Loud: A History of Gay and Lesbian Activism in Australia (St Leonards: Allen \& Unwin, 2000); Yorick Smaal and Graham Willett, eds, Out Here: Gay and Lesbian Perspectives VI (Clayton: Monash University Publishing, 2011); Yorick Smaal and Graham Willett, eds, Intimacy, Violence and Activism: Gay and Lesbian Perspectives on Australasian History and Society (Clayton: Monash University Publishing, 2013). 
homosexual subcultures and most concentrate on the period after $1945 .{ }^{18}$ Such research has highlighted the need for further explorations of the complexity of gay lives in the past and adds to contemporary efforts to seek out positive stories of resilience in the face of persecution. Given the discriminatory and limited nature of past interpretations of homosexuality in Australia generally, and the fact that such discrimination is ongoing, there is also an argument for the educational importance of bringing marginalised narratives into contemporary curricula at tertiary level. Thus my own work took on a dual approach in that I sought both to uncover stories that might add to historical knowledge of homosexuality in 1930s Perth while simultaneously seeking out positive alternative stories of homosexual subcultures that I could communicate to my students.

Because of the traditional neglect of Western Australian queer history as well as the paucity of source material, little is known about attitudes to homosexuality in the state before the 1960s. Sex between men was illegal in WA until December 1989 and could be punished by a custodial sentence of up to 12 years. ${ }^{19}$ Importantly, sex between women was never criminalised and this, somewhat ironically, has led to a relative paucity of sources on lesbianism in Australia before the 1960s. ${ }^{20}$

General histories of sexuality in Australia tell us that, for much of the twentieth century, there was a culture of silence around homosexuality. ${ }^{21}$ In this period, societal opinions on gays and lesbians were partially generated from the limited analyses of homosexuality produced by European medical and scientific authorities. This was in keeping with the representation of homosexuality as a disease or form of mental disorder that necessitated

18 The notable exceptions to this include Bruce Baskerville, "Agreed to Without Debate": Silencing Sodomy in Colonial Western Australia', in Gay and Lesbian Perspectives IV: Studies in Australian Culture, ed. Robert Aldrich and Garry Wotherspoon (Sydney: University of Sydney, 1998), 95-115; Reece Plunkett, 'Making Things Otherwise: An Ethnogenealogy of Lesbian and Gay Social Change in Western Australia' (PhD diss., Murdoch University, 2005); Charlie Fox and Bri McKenzie, 'CAMP and Gay Rights', in Radical Perth Militant Fremantle, ed. Charlie Fox, Bobbie Oliver and Lenore Layman (Perth: Black Swan Press, 2017), 183-192. Other authors do deal with periods earlier than the 1950s. See, for example, Yorick Smaal, 'The 'Leniency Problem': A Queensland Case Study on Sentencing Male Same-Sex Offences, 1939-1948', Women's History Review 21, no. 5 (2012): 793-811, doi.org/10.1080/ 09612025.2012.658182; Dino Hodge, 'Adelaide's Flowering Homosexual Culture: 1939-1972', Flinders Journal of History and Politics 27, (2011): 35-55.

19 Fox and McKenzie, 'CAMP and Gay Rights', 183-84.

20 Reynolds and Robinson, Gay \& Lesbian, Then \& Now, 8. For more on lesbianism in Australia see Rebecca Jennings, Unnamed Desires: A Sydney Lesbian History (Clayton: Monash University Publishing, 2015).

21 Lisa Featherstone, Let's Talk about Sex: Histories of Sexuality in Australia from Federation to the Pill (Newcastle upon Tyne: Cambridge Scholars Press, 2011), 59. 
its inclusion within medical discourse. ${ }^{22}$ However, the apparent link between homosexuality and degenerate behaviour also fed into broader societal concerns in the interwar period. The discourses of eugenics and progressivism were influential on understandings of homosexuality in Australia because they shaped accepted ideas around sexual behaviour and sexual hygiene. ${ }^{23}$ Scientific understandings of human behaviour, so valued in this period just after medicine's Golden Age, understood homosexuality not as a sexual activity but as a personality 'type' that was invariably linked to other forms of deviance including paedophilia. ${ }^{24}$

Primary source documents pertaining to criminal court cases are among the few useful sources on homosexual relationships in 1930s WA. Cases of 'unnatural offence', which from 1903 were heard in the Western Australian Supreme Court, were reported in newspapers and in some of these cases, court records remain. Such sources are, of course, highly problematic in that they often perpetuate the silencing of the accused men. ${ }^{25}$ It thus remains for the researcher to give voice to their stories and understand their experiences through studied interpretation of the sources, informed by an understanding of the social and criminal context of the period. ${ }^{26}$ It is unlikely that all cases of homosexuality brought before the courts were instances of non-consensual sex. Homosexual subcultures existed in all capital cities in Australia during the 1930s, so consensual sex between men did take place and, at times, would have resulted in a court hearing and potentially gaol time. ${ }^{27}$

22 Interestingly, as Featherstone points out, such analysis was generally avoided by Australian doctors. See Lisa Featherstone, 'Even More Hidden from History?: Male Homosexuality and Medicine in Turn-of-the-Century Australia', in Out Here: Gay and Lesbian Perspectives VI, ed. Yorick Smaal and Graham Willett (Clayton: Monash University Publishing, 2011), 61-63.

23 Stephen Garton, 'Eugenics in Australia and New Zealand: Laboratories of Racial Science', in The Oxford Handbook of the History of Eugenics, ed. Alison Bashford and Philippa Levine (Oxford: Oxford University Press, 2012), 4, doi.10.1093/oxfordhb/9780195373141.013.0014; Grant Rodwell, 'Curing the Precocious Masturbator: Eugenics and Australian Early Childhood Education', Journal of Australian Studies 22, no. 59 (1998): 85, doi.org/10.1080/14443059809387426.

24 Featherstone, Let's Talk about Sex, 180-81; Featherstone, 'Even More Hidden from History', 56-68.

25 John Waugh comments on this in relation to colonial sodomy prosecutions in Victoria. See John Waugh, “A gang of judicial assassins”: George Bateson and Colonial Sodomy Laws', in Intimacy, Violence and Activism: Gay and Lesbian Perspectives on Australasian History and Society, ed. Yorick Smaal and Graham Willett (Clayton: Monash University Publishing, 2013), 26.

26 See, for example, how understandings of and prosecutions for sex crimes changed in 1950s Australia. Lisa Featherstone and Amanda Kaladelfos, Sex Crimes in the Fifties (Carlton: Melbourne University Press, 2016), 13.

27 See, for example, Featherstone and Kaladelfos, Sex Crimes in the Fifties, 160-61. 
Yet, in the newspaper reports I examined, representations of 'unnatural offence' cases made little distinction between serial perpetrators of paedophilia and men accused of having sex with other men. ${ }^{28}$ Indeed, all cases of homosexual sex that I have found mentioned in Perth newspapers during this period were represented and understood through a lens of exploitation. For example, two prisoners accused of participating in an 'unnatural act' at the Pardelup prison farm in April 1928 were forced to incriminate each other in court despite the encounter clearly being consensual. ${ }^{29}$ Such interpretations contributed to the stereotype of the homosexual man as morally deviant and inherently criminal and highlight the importance of redressing such misrepresentations.

\section{The Gibson Case}

Throughout my analysis of 'unnatural offence' cases reported in the Western Australian press during the 1930s, the Gibson case stood out. The role of the police in the case was intriguing, and the way the stories of both Keith and Clarence changed throughout the trials suggested much of historical interest. Keith Gibson stood trial on 9 March 1931 before Justice Draper of the Western Australian Supreme Court. At the trial, the apparent victim-Clarence Cummings-initially gave incriminating evidence against the accused, only to recant under cross-examination. When asked why he had made a false claim, Clarence replied that he had been pressured into incriminating Keith by the arresting officers. According to Clarence, detectives Johnston and Doyle had told him he would be institutionalised if he did not provide evidence against the accused. Keith was subsequently found not guilty and discharged. Clarence, on the other hand, was later arrested for perjury and for allowing Gibson to commit an 'unnatural offence' on him and was sent to the Children's Court. ${ }^{30}$

While it is clear that sex between the two men took place, it was the circumstances of that encounter that appear to have determined whether or not one or the other was prosecuted. Either Keith was guilty of having 'carnal knowledge' of Clarence or Clarence was guilty for having allowed

28 See, for example, the case of Peter James Easton Lewis Brown: 'Children's Court, Perth', West Australian, 13 January 1931, 8; “Kathleen Mavourneen” for Sex Pervert', Daily News, 18 March 1931, 6; 'It May Be for Years!', Mirror, 21 March 1931, 12; 'My Unworthy Life', Truth, 22 March 1931, 7.

29 'Down on the Farm: Pleasures at Pardelup. No Real "Prisoners", Daily News, 7 June 1928, 2.

30 'Perjury Charge. Youth Under Arrest', Sunday Times, 29 March 1931, 2; 'Boy Charged with Perjury', West Australian, 27 March 1931, 16. 
Keith to have sex with him. The circumstances of this case appear to show some degree of flexibility in the application of 'unnatural offence' laws in WA at this time. It is unclear why Keith was discharged, given it is evident that sex between the two did take place. Conversely, Clarence was charged with 'allowing an unnatural offence to be committed on him', suggesting that he was viewed as a willing participant. Clarence's age might also have come into consideration here. While boys under the age of 14 were thought to be incapable of taking responsibility for any sex acts they were involved in, boys of 14 and over were considered able to 'resist unwanted advances'. ${ }^{31}$ In WA in 1931, although homosexual sex itself was illegal, the age of consent was 16 for all genders. ${ }^{32}$ As such, Clarence, then 16, was of an age at which consensual sex was permitted and he was deemed able to prevent sexual advances if they were not wanted. His apparent crime in this case, then, was his choice of partner.

It was not this aspect of the case, however, that most piqued my interest, but the apparent role of police coercion in the charging of Keith. Coercion of gay men by police was well known to have occurred in most Australian jurisdictions from the 1950s onward and police mistreatment formed part of some men's defence against sodomy prosecutions in court. ${ }^{33}$ Police would stake out known beats, arrest a group of men and then force those arrested to incriminate others. ${ }^{34}$ The apparent actions of detectives Johnston and Doyle in the Gibson case were thus, perhaps, illustrative of early manifestations of such police harassment.

This, however, was not the truth of the case. The witness statements taken in advance of the trial paint a different story altogether, one that muddied the convenient tale of police entrapment and highlighted something much darker and sadder about the lives of the two men involved. First, it was clear that Clarence was vulnerable at the time of his encounters with Keith. His parents had recently broken up and he had been sent to live with an aunt in a maternity home. ${ }^{35}$ While it is not clear how Keith met Clarence, witness statements reveal that in the 11 months leading up

31 Mark Finnane and Yorick Smaal, 'Some Questions of History: Prosecuting and Punishing Child Sexual Assault', in The Sexual Abuse of Children: Recognition and Redress, ed. Yorick Smaal, Andy Kaladelfos and Mark Finnane (Clayton: Monash University Publishing, 2016), 13.

32 Jill Bavin-Mizzi, 'Sexual Assault', in Historical Encyclopedia of Western Australia, ed. Jenny Gregory and Jan Gothard (Crawley: University of Western Australia Press, 2009), 810.

33 Featherstone and Kaladelfos, Sex Crimes in the Fifties, 14.

34 Fox and McKenzie, 'CAMP and Gay Rights', 184.

35 Statement of George Hugh Cummings, Supreme Court Case File 6007, State Records Office (SRO) Reference AU WA S122-618. 
to December 1930, Keith regularly visited the maternity home to spend time with Clarence and nurses there reported seeing Keith kiss and put his arm around Clarence on these occasions. ${ }^{36}$ Clarence also reported visiting Keith's home in early December 1930 where Keith initiated sex. This relationship between the two continued until Clarence eventually went to live with Keith in late December $1930 .^{37}$

The age disparity between Keith and Clarence also contributed to Clarence's vulnerability in their relationship. In his witness statement, taken 4 February 1931, Clarence describes a great number of sexual interactions between himself and the much older and more experienced Keith. ${ }^{38}$ The most convincing aspect of Clarence's statements was the variety of sex acts he described. Given the social context and what was then known about homosexual sex, it is unlikely that a 16-year-old growing up in 1930s Perth would have had enough knowledge to make up evidence of such events. It was also clear from Clarence's witness statements that the sexual encounters with Keith were often coercive and showed a pattern of increasing intensity in the lead-up to the pair eventually living together in late December 1930. For example, on one occasion, after oral sex, Clarence told Keith that he 'did not like it' and Gibson responded by saying that they would 'cut it out'. This did not, however, result in a ceasing of sexual encounters but an escalation to other sexual acts including, ultimately, anal sex. ${ }^{39}$

Until his eventual reporting to police in January 1931, it seems that Clarence had not expressed any concern about his interactions with Keith. Clarence's father, when interviewed by police, stated that the boy had 'made no complaint to me' about his circumstances. Nor did Clarence's father raise any objection to the pair living together when he visited Keith's house in December 1930. ${ }^{40}$ Annie Bunce, the housekeeper at Keith's flat, also stated to police that she saw nothing suspicious between the two. ${ }^{41}$ Yet, the absence of complaint does not in itself imply unqualified

36 Statement of Catherine Egan, Supreme Court Case File 6007, SRO Reference AU WA S122-618.

37 Statement of Clarence George Edward Cummings, Supreme Court Case File 6007, SRO Reference AU WA S122-618.

38 Statement of Clarence George Edward Cummings, Supreme Court Case File 6007, SRO Reference AU WA S122-618.

39 Statement of Clarence George Edward Cummings, Supreme Court Case File 6007, SRO Reference AU WA S122-618.

40 Statement of George Hugh Cummings, Supreme Court Case File 6007, SRO Reference AU WA S122-618.

41 Statement of Annie Bunce, Supreme Court Case File 6007, SRO Reference AU WA S122-618. 
consent. ${ }^{42}$ It was unusual for child victims of sexual assault to report their abusers to police during this period. Typically cases came to police attention when a parent reported on behalf of their child. ${ }^{43}$ Young victims were also sometimes actively discouraged from reporting to authorities because of the stigma attached to such encounters. ${ }^{44}$ As such, Clarence's ultimate decision to report what had been happening with Keith suggests he was sufficiently uncomfortable with the relationship that he would report this relationship to the police despite such barriers, and highlights his lack of adult support during his period of living away from home.

The testimony of the detective who arrested Keith is also revealing. In the exchange between the accused and the arresting officer, Keith certainly presented as a guilty party. This is unsurprising given that sex between men was illegal and Keith evidently knew why he had been arrested. Indeed, Detective Johnston began the interview with an ominous you know what we want to see you about', and Keith responded with 'I suppose that man ... has been making trouble'. ${ }^{45}$ According to Johnston's testimony, Keith himself brought up the subject of Clarence, asking if 'the boy' had made any accusations against him. ${ }^{46}$ Clarence had made a number of accusations and had given a statement describing the sex acts that had taken place between himself and Keith. Keith was shown this statement and was asked if the boy was lying. After hesitating for 10 or 15 seconds, he responded 'no, I won't say he is telling lies' only to quickly follow with 'I'll take that back. I'll say nothing until I see a solicitor.' ${ }^{47}$

If Johnston's statement is to be believed, Keith clearly admitted to sex with Clarence. Yet, it is difficult fully to understand Keith's responses here. He certainly appears to feel guilty about something, though this does not necessarily imply that he was guilty of sexual assault. His responses could be the result of years of internalised self-hatred and selfdoubt brought about through the negative societal messaging around homosexuality that was prevalent at this time. Neither Keith's responses to police questioning; the statement of Clarence's father; the testimony from

42 Yorick Smaal, 'Boys and Homosex: Danger and Possibility in Queensland, 1890-1914', in Children, Childhood and Youth in the British World, ed. Shirleene Robinson and Simon Sleight (Hampshire: Palgrave Macmillan, 2016), 225, doi.org/10.1007/978-1-137-48941-8_13.

43 Featherstone and Kaladelfos, Sex Crimes in the Fifties, 78.

44 Smaal, 'Boys and Homosex', 224.

45 Statement of John Johnston, Supreme Court Case File 6007, SRO Reference AU WA S122-618.

46 Statement of John Johnston, Supreme Court Case File 6007, SRO Reference AU WA S122-618.

47 Statement of John Johnston, Supreme Court Case File 6007, SRO Reference AU WA S122-618. 
Catherine Egan, the nurse at the maternity hospital; nor the statement of Annie Bunce, the housekeeper, can be taken as proof that a sexual assault occurred. We can, however, look to the detailed statement from the apparent victim, Clarence Cummings, to find evidence that strongly suggests Keith Gibson was guilty of assault.

Nothing in Clarence's witness statement to police indicated that he was an enthusiastic participant in his relationship with Keith. Indeed, he had expressed to Keith that he was not comfortable with what was happening and this had not resulted in any noticeable change in Keith's behaviour. Looking at the events as described in the witness statements through a contemporary lens, Keith's behaviour in the lead-up to his sexual relationship with Clarence-his regular visits to the maternity home over 11 months, his evident affection towards the young man-could be seen as grooming. Keith's conduct follows patterns observed in other cases of child sexual assault documented during this period in Australia, assaults that were largely made possible by the unfettered access to public places enjoyed by men and boys. ${ }^{48}$ Clarence's age and manifest vulnerability after the break-up of his family also lend weight to the idea that this was not a relationship that he necessarily wanted. Clarence's descriptions of the intimacy between himself and Keith also highlight Clarence's own need for security and love from an adult figure. According to Clarence's witness statements, Keith told him that he 'would never do it to anyone else' and this was accompanied by kissing and hugging.

Evidence from the two trials also shows that Keith sought to cover his tracks. For example, it later emerged that Keith had visited Clarence on the night before the first trial and had convinced him to recant his evidence. This was the reason for Clarence's apparent perjury in court. At his own trial, Clarence admitted that his accusations against detectives Johnston and Doyle were false and that no threat of institutionalisation had ever been made. ${ }^{49}$ It emerged in later years that Keith also had a number of aliases and was involved in other minor criminal behaviour. ${ }^{50}$

The story of the Gibson case does serve as an opportunity to highlight the marginalisation of gay men within this specific temporal and geographic context. The sources, limited as they are, show an almost complete

48 Finnane and Smaal, 'Some Questions of History', 14; Smaal, 'Boys and Homosex', 224.

49 'Charge of Perjury', Western Argus, 7 April 1931, 23.

50 'Inquest', Northern Times, 18 November 1948, 1. 
absence of Keith's voice. As a man accused of an 'unnatural offence', we hear very little from him. No witnesses appeared for him at his trial and it appears he took no active part in his own defence. Indeed, we hear about Keith's life only three more times in the newspapers. A year after his trial in 1932, he failed to appear in court after refusing to give his name to police officers, though it appears he was never prosecuted for anything in this instance. ${ }^{51}$ In 1936, he was fined $£ 50$ for his part in an illegal betting shop operation. ${ }^{52} \mathrm{He}$ is mentioned again in 1948, this time identified as a man who took his own life, then aged $52 .{ }^{53}$

My analysis of the witness statements in the Gibson case brought into question any suggestion that this case could form part of an effort to correct historical misrepresentations of homosexual relationships in the past. Indeed, it appeared I had found just what I did not want to find - a reinforcement of the relationship between homosexuality and criminal behaviour. However, as Yorick Smaal has highlighted, cases such as this that are based on criminal trial evidence are uniquely difficult to analyse. Historians working in these areas both 'recognize potentially non-harmful relationships between adults and youths within narratives of identity and subculture' and also 'consider their evidence within narratives of gendered exploitation and abuse'.${ }^{54}$ As such, there remains an ambivalence to the relationship between Keith and Clarence that cannot ever be fully understood.

\section{Self-Reflexivity and the Gibson Case}

In this case, the inherent challenges of harnessing the past for use in the present context were highly visible and emphasised the importance of selfreflexivity in historical practice. I began with an intention to draw attention to past narratives that emphasised the unwarranted criminalisation and demonisation of gay men - all in an effort to bring about a deeper understanding and awareness of marginalised voices. But what I found was evidence that only served to reinforce negative stereotypes.

51 'Keith Edwin Gibson', Daily News, 19 September 1932, 1.

52 ' $£ 325$ in Betting Fines’, Daily News, 30 June 1936, 3.

53 'Inquest', Northern Times, 18 November 1948, 1.

54 Smaal, 'Boys and Homosex', 222. 
Indeed, approaches to historical research that utilise the past for the purposes of the present have been suggested by other scholars as problematic. As Alya Aglan has noted:

The use of the present to ask questions of the past is perfectly legitimate, but the past is also increasingly called upon to provide answers for the present, which is much more controversial. Unfinished business in the present, such as the pain suffered by the victims of past persecution, has led to a mobilisation of the past in a particular way to highlight persecution and oppression, for which apology, compensation and justice are demanded in the present. The past becomes not an objective account of 'how things happened', but a moral drama in which champions of right and perpetrators of wrong are held to account for the benefit of a contemporary audience in search of redress. ${ }^{55}$

Such research approaches are necessarily subjective in their analysis and scope, calling into question their value as a source of historical 'truth'. Yet, as the application of the philosophical linguistic turn to the discipline of history has made clear, the pursuit of true historical objectivity is a futile endeavour. The adoption of discourse analysis in history assisted historians 'to imagine and construct alternative pasts in terms of their ethical and political commitments in the present and their visions of alternative futures'. ${ }^{56}$ This adaptation was also linked to the rise of social history and its relationships to 1960s political and social movements. So, while research that pre-empts outcomes can always be considered problematic, all research, whether so acknowledged or not, has an agenda. Using research to seek outcomes in the present is not, therefore, necessarily ahistorical.

In teaching terms, my analysis of the Gibson case did present a problem, however. On the surface, it was not an appropriate case study for teaching about gay and lesbian history in Australia because the likely sexual assault in the case only served to reinforce negative stereotypes about homosexuality. However, the case was an example of how important selfreflexivity is to successful historical research. That message was one that could be communicated to students.

55 Alya Aglan, 'An Excess of the Present in the Past', in Writing Contemporary History, ed. Robert Gildea and Anne Simonin (London: Hodder Education, 2008), 170.

56 John E. Toews, 'Linguistic Turn and Discourse Analysis in History', in International Encyclopedia of Social and Behavioural Sciences, 2nd edn, volume 14, ed. James Wright (Elsevier, 2015), 206, doi.org/ 10.1016/B978-0-08-097086-8.62143-8. 
It was to this end that I discussed my own research experience in looking into the Gibson case with third-year history students who were themselves engaging in their first major local history projects. Much of my work in the context of teaching these specific students involves practical instruction and discussions around source analysis and the challenges of research. The seminar format allowed for open conversations between myself and students. Such conversations were in themselves self-reflexive because they necessitated the internal analysis of process, inherent bias and researcher assumptions. But they also encouraged ongoing self-reflexivity in both the students and myself as an instructor. In this context, self-reflexive practice became about conscious questioning of research choices. For example, students were encouraged to ask themselves: Why have I chosen this topic for my research project? What contemporary influences am I bringing to my analysis? Why have I privileged one primary source over another? Such questions are very important for all researchers at any stage of instruction.

In my case, I explained that my own passion for LGBTQI+ history coupled with my commitment to social justice and efforts to 'queer' the history curriculum had created a situation in which my research began by pre-empting outcomes. Through my preparedness to be open about my intentions for my research into homosexual subcultures in interwar WA, I was able to explain to students how my process had, in effect, 'gone wrong'. Beginning research with presumptions about what you will find and with intentions for the contemporary uses of that research can lead to problematic results. Open conversations like these take on a unique power for students when a teacher shares their own research failings. We do, as McGrath rightly suggests, have a responsibility to share the ups and downs of our research journey with our students and doing so can lead to richer and more fulfilling teaching experiences.

The application of self-reflexivity in my teaching is an ongoing and evolving process that was sparked into action through my experience with researching the Gibson case. In future iterations of my third-year class, self-reflexivity will be given a more prominent place in discussions around process and methodology. The experience has also necessitated a continuing self-reflexivity that has required deeper questioning of how I choose to situate myself as a teacher, historian and LGBTQI+ ally. My positioning as a white, middle-class, cis-gender woman gives me access to, among other advantages, higher education and a privileged position as 
a tertiary teacher, but it also gives me an understanding of the structural and institutionalised nature of sexism and this has allowed me to relate to the experiences of outsider identities.

Knowing and working closely with colleagues and friends who identify as queer and actively pursuing my role as a straight ally has fed into my desire to work actively against queer silencing in my teaching. In her discussion of history teaching and the use of vignettes, education scholar Philippa Hunter utilises Wendy Lutrell's concept of 'reflexive knowing' to explain her own pedagogical approaches. ${ }^{57}$ In a similar way, my own 'knowing' in relation to the 'discursive tensions that embed power relations in curriculum and pedagogy ${ }^{58}$ has led me to pursue restorative work in my history teaching. My recognition that my positioning gives me privilege spurs me on to use that privilege in ways that allow me to work as an advocate for LGBTQI+ people. Yet, self-reflexivity in this context also requires a recognition that my intimate connection and passion for these restorative pedagogical approaches can, and in this case did, lead to problematic outcomes.

\section{Conclusion}

Research into queer histories that seeks to shine a light on untold stories is highly important in our current context and links up with contemporary efforts to 'queer' curricula at primary and secondary level. My study of homosexual subcultures in interwar WA thus formed part of my commitment to both queer history and more inclusive pedagogical approaches. In investigating a unique Western Australian 'unnatural offence' case, I was hoping to address gaps in historical knowledge, include previously marginalised perspectives in my teaching work and offer students alternative stories of homosexual subcultures of the past.

The Gibson case did not easily lend itself to this type of analysis, however. Instead, the case brought my research decisions and aims into question, necessitating the introduction of a process of self-reflexivity that will continue to influence my work as both teacher and researcher. While the events of the Gibson case reinforced negative stereotypes about

57 Philippa Hunter, 'Using Vignettes as Self-Reflexivity in Narrative Research of Problematised History Pedagogy', Policy Futures in Education 10, no. 1 (2012): 93, doi.org/10.2304/pfie.2012.10.1.90. 58 Hunter, 'Using Vignettes', 93. 
homosexuality, thus making the case a problematic historical case study to bring to students, I did find a path that allowed me to put the case and my contradictory findings to good use in the classroom. Through discussion of my research experience as well as encouragement for students to engage in conscious questioning of their own role in their research, I was able to introduce students to the notion of self-reflexivity and demonstrate my own engagement with that ongoing work. As such, encouraging self-reflexivity in student historians was an unexpected side benefit of the failures of the Gibson case to provide what I needed for my contemporary agenda. 
This text is taken from ANU Historical Journal II: Number 2, published 2020 by ANU Press, The Australian National University, Canberra, Australia.

doi.org/10.22459/ANUHJII.2020.04 